\title{
Koi Herpes Virus (KHV) Disease ${ }^{1}$
}

Kathleen H. Hartman ${ }^{2}$, Roy P.E. Yanong ${ }^{2}$, B. Denise Petty ${ }^{3}$, Ruth Francis-Floyd ${ }^{3}$ and Allen C. Riggs ${ }^{4}$

\section{Introduction}

Koi herpes virus (KHV), a viral disease highly contagious to fish, may cause significant morbidity (sickness or disease) and mortality in common carp (Cyprinus carpio) (Hedrick et al., 2000; OATA, 2001). This species is raised as a foodfish in many countries and has been selectively bred for the ornamental fish industry, where it is known as koi. Historically, the first outbreak of KHV was reported in 1998 and confirmed in 1999 in Israel. Since then, other cases have been confirmed in the United States, Europe and Asia (Hedrick et al., 2000; OATA, 2001; Anonymous, 2003). This information sheet is intended to inform veterinarians, biologists, culturists, and hobbyists about KHV.

\section{What Is KHV?}

$\mathrm{KHV}$ is currently classified as a DNA-virus belonging to the virus family Herpesviridae (i.e., a herpes virus). Although there has been some scientific discussion regarding the accuracy of this classification (Ronen et al., 2003), more recent work (Waltzek et al., 2004) shows strong evidence that $\mathrm{KHV}$ is indeed a herpesvirus, based on morphology and genetics. KHV disease has been diagnosed in koi and foodfish carp (Hedrick et al., 2000; OATA, 2001). Other related cyprinid species such as the common goldfish (Carassius auratus) and grass carp (Ctenopharyngodon idella) seem to be unaffected by KHV. As with other herpes viral infections, $\mathrm{KHV}$ is believed to remain in the infected fish for life, thus exposed or recovered fish should be considered as potential carriers of the virus (OATA, 2001).

KHV disease may cause $80-100 \%$ mortality in affected populations, and fish seem most susceptible at water temperatures of $72-81^{\circ} \mathrm{F}$ $\left(22-27^{\circ} \mathrm{C}\right)(\mathrm{OATA}, 2001)$. This viral disease affects fish of various ages, but cohabitation studies show that fry have a greater susceptibility than mature fish (Perelberg et al., 2003).

\section{What Are the Signs of KHV?}

Clinical signs of KHV are often non-specific. Onset of mortality may occur very rapidly in affected populations, with deaths starting within 24-48 hours after the onset of clinical signs. In experimental studies, $82 \%$ of fish exposed to the virus at a water temperature of $22^{\circ} \mathrm{C}$ died within 15 days (Ronen et al., 2003). KHV infection may produce severe gill lesions and high mortality rates. In some cases, secondary bacterial and parasitic infections may be the most obvious problem, masking the damage caused by the primary viral infection. Behaviorally, affected fish often remain near the surface, swim lethargically, and may exhibit respiratory distress and uncoordinated swimming.

\footnotetext{
${ }^{1}$ This document is Fact Sheet VM-149, one of a series from the Department of Large Animal Clinical Sciences (College of Veterinary Medicine), Florida Cooperative Extension Service, Institute of Food and Agricultural Sciences, University of Florida. First published: June 2004. Please visit the EDIS Web Site at http://edis.ifas.ufl.edu.

${ }^{2}$ Kathleen H. Hartman, Courtesy Assistant Professor, and Roy P.E. Yanong, Assistant Professor, Tropical Aquaculture Laboratory, Department of Fisheries and Aquatic Sciences, Florida Cooperative Extension Service, Institute of Food and Agricultural Sciences, University of Florida, Ruskin, FL 33570 .

${ }^{3}$ B. Denise Petty, Clinical Assistant Professor, and Ruth Francis-Floyd, Professor, Department of Large Animal Clinical Sciences (College of Veterinary Medicine) and Department of Fisheries and Aquatic Sciences, Florida Cooperative Extension Service, Institute of Food and Agricultural Sciences, University of Florida, Gainesville, FL 32611.

${ }^{4}$ Allen C. Riggs, Aquatic Veterinary Services, 7200 SW Eighth Ave, Unit 095, Gainesville, FL 32607.

The Institute of Food and Agricultural Sciences (IFAS) is an Equal Employment Opportunity - Affirmative Action Employer authorized to provide research, educational information and other services only to individuals and institutions that function without regard to race, creed, color, religion, age, disability, sex, sexual orientation, marital status, national origin, political opinions or affiliations. For information on obtaining other extension publications, contact your county Cooperative Extension Service office. Florida Cooperative Extension Service/Institute of Food and Agricultural Sciences/University of Florida/Larry R. Arrington, Interim Dean
} 
External signs of KHV may include gill mottling with red and white patches (Figure 1) (similar to columnaris disease), bleeding gills, sunken eyes, pale patches or blisters on the skin. Microscopic examination of gill biopsies often reveals high numbers of bacteria and various parasites (Hedrick et al., 2000; OATA, 2001; Goodwin, 2003). Internal signs of KHV are inconsistent and nonspecific, but they may include adhesions in the body cavity and a mottled appearance of internal organs (Hedrick et al., 2000; Goodwin, 2003).

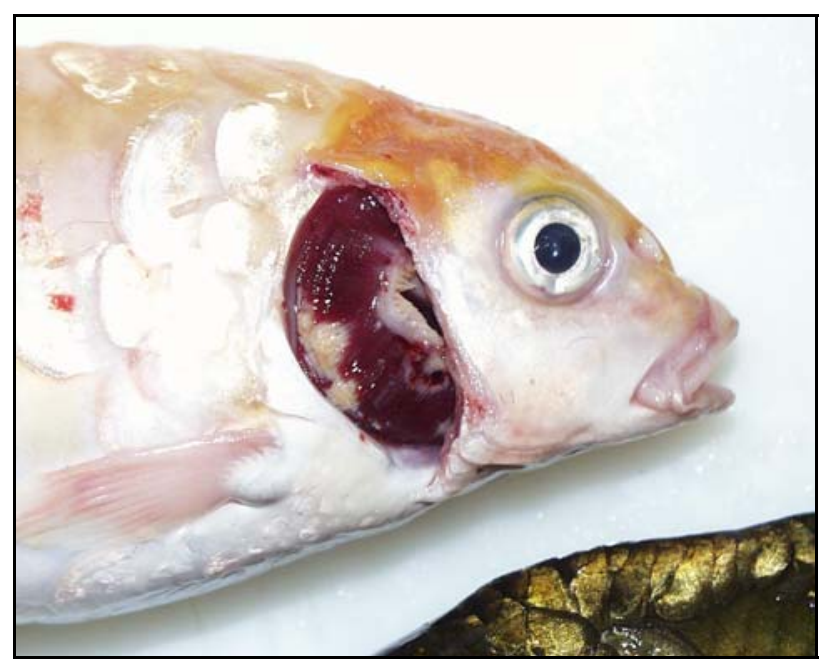

Figure 1. Koi with KHV often show gill mottling with red and white patches. This mottling can appear similar to that seen in the gills of fish with columnaris disease. Photograph courtesy of Andy Goodwin, University of Arkansas, Pine Bluff.

\section{How Do Fish Get Infected with KHV?}

The herpes virus that is responsible for KHV seems to spread in the same ways as most herpes viruses. Methods of transmission include direct contact with infected fish, with fluids from infected fish, and/or with water or mud from infected systems. Depending upon water temperature, fish that are exposed and susceptible may become infected and either develop the disease and die or become carriers of the virus (OATA, 2001). Goldfish and other fish in the carp family are not susceptible to KHV disease, and they do not appear to act as carriers of the virus (Perelberg et al., 2003; Ronen et al., 2003).

\section{How Does Water Temperature Affect KHV Disease?}

The virus appears to have an incubation period of 14 days following the introduction of infected fish to naïve fish (fish that have not been exposed before) (OATA, 2001; Ronen et al., 2003).

However, incubation may be longer, indicating that appropriate temperature and possibly a second trigger may be necessary for outbreaks to occur. Mortality related to KHV disease typically occurs between $64^{\circ} \mathrm{F}$ and $81^{\circ} \mathrm{F}\left(18-27^{\circ} \mathrm{C}\right)$. Almost no mortalities occur below $64^{\circ} \mathrm{F}$, and there has been no reported occurrence of the disease at or above $86^{\circ} \mathrm{F}\left(30^{\circ} \mathrm{C}\right)(\mathrm{OATA}, 2001$; Goodwin, 2003).

\section{How Do I Know if My Fish Have KHV?}

Positive diagnosis of KHV requires the assistance of a fish health specialist and a fish disease diagnostic laboratory, and it may be accomplished by several methods. Direct methods involve procedures that look for actual virus or "pieces" of virus. Indirect methods involve procedures that do not look for the actual virus or parts of the virus, but instead look for an immune response (such as antibodies) by the fish.

Direct methods include: 1) virus isolation and identification (i.e., growing the virus) using koi fin (KF) cell lines and 2) PCR techniques (i.e., testing for the presence of KHV genes). For these direct, confirmatory, diagnostic tests, fish must be euthanized prior to sample collection; no non-lethal diagnostic test is available. However, in some cases, positive results may be obtained from submission of gill clips (although this may not be 100\% accurate, either, and a full necropsy with submission of internal organs will yield more definitive results).

Indirect tests for KHV include ELISA testing, which looks for antibodies produced by the fish against the virus (Hedrick et al., 2000; OATA, 2001; Goodwin, 2003). ELISA testing can provide evidence that a fish was at one time exposed to and infected with KHV. Unfortunately, because indirect tests like the ELISA cannot determine if the fish is still infected with virus, it is not recommended as a primary diagnostic tool. 


\section{How Does KHV Differ from Other Viral Diseases?}

It is important to differentiate KHV from other viruses that may cause disease in common carp and koi. The two other viral diseases recognized in carp are spring viremia of carp (SVC) and carp pox (CHV-1). These diseases have significantly different management and regulatory implications (Table 1).

Spring viremia of carp disease is caused by an RNA virus, Rhabdovirus carpio, and has been reported in common carp (such as koi), grass carp, bighead carp (Aristichthys nobilis), silver carp (Hypophthalmichthys molitrix), Crucian carp (Carassius carassius), and common goldfish.

SVC outbreaks have occurred in Europe, the Middle East, Russia and the United States. Although SVC was not recognized as a viral disease until 1971 (Fijan), SVC-like diseases have been described in historical records of northern Europe for centuries. SVC may cause high morbidity and mortality $(70 \%)$ in affected populations (see UF/IFAS factsheet VM142, Spring Viremia of Carp). SVC usually causes disease when water temperatures range between $41^{\circ} \mathrm{F}\left(5^{\circ} \mathrm{C}\right)$ and $64^{\circ} \mathrm{F}$ $\left(18^{\circ} \mathrm{C}\right)$, unlike $\mathrm{KHV}$, which typically causes outbreaks at higher water temperatures. SVC is listed as a notifiable disease by the Office International des Epizooties (OIE) (Office International des Epizooties, 2003). Thus, when a case of SVC has been confirmed in the United States by a USDA-approved laboratory, the diagnostician must promptly notify the state veterinarian and appropriate USDA-APHIS Veterinary Services officials.

Carp pox disease, or cyprinid herpesvirus (CHV-1), is caused by a different herpesvirus (Herpesvirus cyprini) that has a wide geographic distribution and affects common carp and koi. CHV typically causes smooth raised growths ("wart-like masses") on skin and fins of older fish, but it may be associated with high mortality in fish less than two months of age (Hedrick et al., 2000). Carp pox is not a reportable or notifiable disease in the United States. Water temperatures above $68^{\circ} \mathrm{F}$ $\left(20^{\circ} \mathrm{C}\right)$ help reduce the skin and fin growths on older fish, but do not eliminate the virus from the fish. In mature fish, CHV-1 is typically a nonlethal, self-limiting disease.

\section{Is There Treatment for KHV?}

There is no known treatment for KHV. Antiviral drugs are not currently available to treat KHV or any other viral diseases of cultured fish. Studies have shown that fish may develop a natural resistance following viral exposure if water temperatures are increased to $86^{\circ} \mathrm{F}\left(30^{\circ} \mathrm{C}\right)$ (Ronen et al., 2003). However, this technique only marginally increases survival rates and artificially raising water temperatures in holding facilities above $80^{\circ} \mathrm{F}$ may result in an increased occurrence of other more common bacterial and parasitic diseases. High water temperatures are not generally recommended for routine husbandry and management of koi and common carp. In addition, and more importantly, there is the concern that fish exposed to the virus previously or those exposed at high water temperatures may become carriers of the virus, even though they do not develop clinical signs. These carrier fish may spread this disease to new fish that have not been exposed before

Currently there is no vaccine against KHV. However, preliminary experimental vaccine studies using intraperitoneal injection of a live attenuated virus demonstrated that fish developed high antibody titers, were immune to the disease and survived a challenge (Ronen et al., 2003).

Because KHV outbreaks have caused large losses at koi and common carp facilities, and because there is still some concern over the possibility that survivors are carriers, anyone with koi and common carp that have been diagnosed with KHV should consider depopulation (eliminating the entire population) as a good option. This approach should be followed by disinfection of all materials and systems that have contacted the infected fish.

Viral particles may be active in water for at least four hours (Perelberg et al., 2003). However, common disinfection protocols (see below) may be used to eliminate the virus from water systems and equipment effectively (see UF/IFAS Fact Sheet VM-87 Sanitation Practices for Aquaculture Facilities). Prior to disinfection, equipment should be cleaned of debris or organic build-up, as these 
may reduce the effectiveness of the disinfectant. Chlorine solutions (i.e., household bleach) may be used to disinfect large equipment or systems without fish. The recommended protocol for chlorine is $200 \mathrm{ppm}(200 \mathrm{mg} / \mathrm{L})$ for one hour (Noga, 1996). Proper dosing of this depends upon the type of chlorine used. For household bleach, which is $5.25 \%$ sodium hypochlorite per liter, 35 milliliters per gallon of water will give $200 \mathrm{mg} / \mathrm{L}$ final concentration(Noga, 1996).

Quaternary ammonium chloride compounds may also be used for systems and equipment. Quaternary ammonium compounds are more gentle on nets than chlorine solutions. The recommended quaternary ammonium compound (QAC) treatment is $500 \mathrm{ppm}(500 \mathrm{mg} / \mathrm{L})$ for one hour (Noga, 1996).

Proper dosing of QACs depends upon the type/concentration in the mixture used, because concentrations will vary depending upon the product used. Some QACs are $10 \%$ active ingredient, some are $50 \%$ active ingredient. For instance, Roccal D-Plus ${ }^{\circledR}$ (Pharmacia \& Upjohn Company, Pfizer) is approximately $24 \%$ active ingredient; therefore, a final treatment concentration of $500 \mathrm{mg} / \mathrm{L}$ would require about $7.9 \mathrm{~mL}$ of Roccal D-Plus ${ }^{\circledR}$ per gallon of water. Rinse thoroughly after disinfection to eliminate residual disinfectant.

\section{How Can KHV Be Prevented?}

Quarantine is the most dependable method to avoid introducing KHV to a naïve population. To apply a quarantine effectively, all new fish must be kept in a separate tank or system, and ideally in a different building or area from the resident fish. Resident fish should be fed, handled, and maintained before the new fish. The quarantined fish require equipment such as nets, buckets, and siphon hoses that are used only for them. In addition, disinfectant foot baths and hand washes should be used by any personnel on entering and leaving the quarantine area. Fish should be quarantined for a minimum of 30 days. The best way to prevent KHV is to know your fish suppliers and have a good working relationship with them.
Prior to obtaining fish, ask if they have had any major unexplained losses. Monitoring and testing for KHV may be done by laboratory tests (as described above), so if suppliers have had major losses and have not had their fish checked by a fish disease diagnostic laboratory, KHV should be considered as one possible cause. These suppliers should be encouraged to have any remaining fish tested for KHV by a capable laboratory, and purchases from these suppliers may be problematic.

To minimize the spread of KHV disease, place koi coming from different suppliers into separate systems, and use very careful disinfection and sanitation between systems. This means making sure employees carefully wash and disinfect their hands and arms in between contact with different systems, having separate nets and other equipment, installing footbaths with disinfectant, and using other standard techniques.

Koi hobbyists are encouraged to promote the use of the English style of koi show, which keeps koi separated during the show and judging.

Additionally, separate nets and equipment should be used by all participants for their own fish. The Japanese style of show, in which koi from different owners are placed together in the same tank, may result in spread of the disease among susceptible fish. Regardless of the show style, fish returning from shows should be quarantined (that is, separated from other koi) for an absolute minimum of three weeks prior to being placed back into the general population.

New koi should be quarantined and observed for three to four weeks prior to addition into existing populations of koi. At the end of this quarantine period and before placing all fish together, place several new koi with several koi from the established population in a separate area away from the rest of the established population and watch them for signs of disease. This "test" can help determine with a smaller number of fish whether placing the two populations together following quarantine could cause problems. 


\section{If I Suspect My Koi Have KHV Disease or if I Want More Information on the Disease, Whom Should I Contact?}

For testing or information, contact:

In Gainesville:

Ruth Francis-Floyd

University of Florida

(352) 392-9617 Ext 229

In Tampa/Ruskin:

Tropical Aquaculture Laboratory

University of Florida

Roy Yanong

(813) 671-5230 Ext 104

Denise Petty

(813) 671-5230 Ext 114

\section{What Are the Regulatory Considerations Associated with KHV?}

$\mathrm{KHV}$ is not a reportable or notifiable disease in the United States. However, SVC is notifiable (see UF/IFAS Fact Sheet VM-142, Spring Viremia of Carp), so if SVC may be a possible cause of heavy mortalities, both KHV and SVC testing should be performed.

\section{What is the Zoonotic Potential Associated with KHV?}

The herpes virus responsible for causing KHV disease in fish will not cause disease in humans. There is no zoonotic concern with KHV. 
Table 1. Comparison of Koi Herpes Virus (KHV), Spring Viremia of Carp (SVC) and Carp Pox (CHV). ${ }^{1}$

\begin{tabular}{|c|c|c|c|}
\hline & \multicolumn{3}{|c|}{ Viral Disease } \\
\hline & Koi Herpes Virus Disease & Spring Viremia of Carp Disease & Carp Pox Disease \\
\hline Synonyms & $\begin{array}{l}\text { Koi virus; carp nephritis and gill } \\
\text { necrosis virus (CNGV);cyprinid } \\
\text { herpesvirus } 3 \text { (CyHV-3) }\end{array}$ & Infectious dropsy of carp & $\begin{array}{l}\text { Cyprinid herpesvirus-1; koi pox; carp } \\
\text { herpesvirus; herpesviral epidermal } \\
\text { proliferation in carp (HEPC); } \\
\text { herpesvirus septicemia in carp (HSC) }\end{array}$ \\
\hline Abbreviation & $\begin{array}{l}\text { KHV; [suggested but not yet } \\
\text { accepted: CNGV; CyHV-3] }\end{array}$ & SVC, SVCV & $\mathrm{CHV}$; CHV-1 CyHV-1 \\
\hline Viral Agent & Herpesvirus (DNA virus) & $\begin{array}{l}\text { Rhabdovirus } \\
\text { Rhabdovirus carpio (RNA virus) }\end{array}$ & $\begin{array}{l}\text { Herpesvirus } \\
\text { Herpesvirus cyprini (DNA virus) }\end{array}$ \\
\hline Species Affected & Common carp/koi carp & Common carp/koi carp, goldfish & Common carp/koi carp \\
\hline Water Temperature & $64-81^{\circ} \mathrm{F}\left(18-27^{\circ} \mathrm{C}\right)$ & $41-64^{\circ} \mathrm{F}\left(5-18^{\circ} \mathrm{C}\right)$ & $<68^{\circ} \mathrm{F}\left(<20^{\circ} \mathrm{C}\right)$ \\
\hline Transmission & $\begin{array}{l}\text { Direct contact } \\
\text { Fecal material } \\
\text { Infected water/mud }\end{array}$ & $\begin{array}{l}\text { Fecal material } \\
\text { Infected water/mud } \\
\text { Vertical transmission }\end{array}$ & Direct contact \\
\hline Age Susceptibility & $\begin{array}{l}\text { Young fish more susceptible than } \\
\text { mature fish }\end{array}$ & $\begin{array}{l}\text { Young fish more susceptible than } \\
\text { mature fish }\end{array}$ & $\begin{array}{l}\text { Young fish more susceptible than } \\
\text { mature fish }\end{array}$ \\
\hline $\begin{array}{l}\text { Clinical Signs } \\
\text { Behavioral }\end{array}$ & $\begin{array}{l}\text { Lethargy } \\
\text { Swim close to the surface } \\
\text { Respiratory distress } \\
\text { Uncoodinated swimming }\end{array}$ & $\begin{array}{l}\text { Lethargy } \\
\text { Stay near tank bottom } \\
\text { Awkward swimming }\end{array}$ & None \\
\hline External & $\begin{array}{l}\text { Variable signs } \\
\text { Gill necrosis } \\
\text { Sunken eyes } \\
\text { Secondary bacterial and parasitic } \\
\text { infections }\end{array}$ & $\begin{array}{l}\text { Signs of septicemia: } \\
\text { exophthalmia, petechial skin } \\
\text { hemorrhage, abdominal distention, } \\
\text { bloody mucus from vent }\end{array}$ & Smooth, raised, wart-like skin lesions \\
\hline Internal & Few, variable signs & $\begin{array}{l}\text { Ascites, edema of internal organs, } \\
\text { bloody catarrhal inflammation of the } \\
\text { intestine }\end{array}$ & None \\
\hline $\begin{array}{l}\text { Confirmatory } \\
\text { Diagnosis }\end{array}$ & $\begin{array}{l}\text { - } \text { CPE on cell culture on KF-1 } \\
\text { (laboratory diagnostics required) } \\
\text { - PCR } \\
\text { (laboratory diagnostics required) }\end{array}$ & $\begin{array}{l}\text { - } \mathrm{CPE} \text { on cell culture on FHM and } \\
\text { KF-1 (laboratory diagnostics } \\
\text { required) } \\
\text { - PCR } \\
\text { (laboratory diagnostics required) }\end{array}$ & $\begin{array}{l}\text { CPE on cell culture on FHM } \\
\text { (laboratory diagnostics required) }\end{array}$ \\
\hline $\begin{array}{l}\text { Regulatory } \\
\text { Considerations }\end{array}$ & NONE & $\underline{\text { NOTIFIABLE }}^{2}$ & NONE \\
\hline Treatment & NONE & NONE & NONE \\
\hline Prevention/Control & $\begin{array}{l}\text { Depopulate affected stocks; } \\
\text { purchase fish from known reputable } \\
\text { source; keep susceptible species } \\
\text { separated; enforce biosecurity } \\
\text { precautions }\end{array}$ & $\begin{array}{l}\text { Depopulate affected stocks; } \\
\text { purchase fish from known reputable } \\
\text { source; keep susceptible species } \\
\text { separated; enforce biosecurity } \\
\text { precautions } \\
\text { Increase temp }>68^{\circ} \mathrm{F}\left(>20^{\circ} \mathrm{C}\right)\end{array}$ & $\begin{array}{l}\text { Depopulation generally not required } \\
\text { for older fish; infected fish are } \\
\text { carriers } \\
\text { Increase temp }>68^{\circ} \mathrm{F}\left(>20^{\circ} \mathrm{C}\right) \text { to } \\
\text { reduce skin lesions }\end{array}$ \\
\hline Disinfection & $\begin{array}{l}\text { - Chlorine, } 200 \text { ppm, } 1 \text { hour } \\
\text { - Quaternary ammonium compounds, } \\
500 \text { ppm for } 1 \text { hour for nets and any } \\
\text { other equipment that has been in } \\
\text { contact with infected fish/water and } \\
\text { that will not withstand chlorine } \\
\text { disinfection }\end{array}$ & $\begin{array}{l}\text { - Chlorine, } 500 \mathrm{ppm}, 10 \text { minutes } \\
\text { - gamma/UV radiation } \\
\text { - } \mathrm{pH}<4.0 \text { or }>10.0 \\
\text { - heat } 60^{\circ} \mathrm{C} \text { for } 15 \mathrm{~min}\end{array}$ & $\begin{array}{l}\text { - Chlorine, } 200 \text { ppm, } 1 \text { hour } \\
\text { - Quaternary ammonium compounds, } \\
500 \text { ppm for } 1 \text { hour (for nets) }\end{array}$ \\
\hline
\end{tabular}




\section{Glossary of Terms Used}

Adhesions
Ascites
Attenuated
Catarrhal inflammation
CHV-1
Common carp
CPE

Edema

ELISA

Exophthalmia

FHM

Intraperitoneal

KHV

Koi

Morbidity

Notifiable disease

OATA

PCR

Petechial skin hemorrhage

Reportable disease

Self-limiting

Septicemia

SVC

Vertical transmission

Zoonotic areas of internal tissues that stick together because of inflammation

dropsy; a build up of fluid in the body cavity

weakened; less pathogenic/disease-causing

inflammation of the mucus membranes

Cyprinid herpesvirus-1, the virus that causes carp/koi pox

Cyprinus carpio; common carp are the original species of fish from which koi were developed as a color/fancy variety/strain/breed

Cytopathic Effect; different viruses will kill different cells used to grow them in culture in certain ways; this is called the cytopathic effect

a build up of fluids within tissues, cells, or body cavities (ascites is a build up of fluid primarily in the body cavity)

Enzyme-linked immunosorbent assay: one lab method used to detect the presence of a virus, virus product, or antibody to a virus

bulging of the eyes; popeye

fat head minnow cell line: a type of tissue (cell-line) used to grow some viruses outside of a fish, in the laboratory

intracoelomic, within the body cavity

koi herpesvirus, the name of the virus that causes koi herpesvirus disease

a strain/variety of common carp that has been bred for scale and color pattern as a pond/ornamental fish

disease or sickness

A disease which must, by law, be reported to the proper federal (USDA-APHISVeterinary Services) and state (Dept. of Agriculture and Consumer Services, state veterinarian) when positively diagnosed

Ornamental Aquatic Trade Association; a British organization representing the interests of ornamental fish importers, breeders, wholesalers, retailers, and manufacturers

Polymerase $\underline{\text { Chain }}$ Reaction; this is an advanced biochemical test used to identify the presence of specific pieces of an organism's genes (DNA)

small, pinpoint hemorrhages (bloody areas) on the skin

same as notifiable disease

does not cause major disease, and usually heals or resolves on its own

a bacterial infection that spreads and travels through the blood to other organs

spring viremia of carp

spread of a disease from parents to offspring, through eggs or sperm

this is the term used to describe a disease of animals (e.g., fish) that can be spread to, and cause disease in, humans 


\section{References}

Anonymous. 2003. Herpes virus kills 860 tons of carp. The Japan Times, Online. November 3, 2003. http://www.japantimes.co.jp/cgibin/getarticle.p15?nn20031103a8.htm

Goodwin, A. 2003. Differential Diagnosis: SVC vs. KHV in Koi. Fish Health Newsletter, AFS/FHS. 31: 1, 9-13.

Hedrick, R.P., O. Gilad, S. Yun, J.V. Spangenberg, G.D. Marty, R.W. Nordhausen, M.J. Kebus, H. Bercovier, and A. Eldar. 2000. A herpesvirus associated with mass mortality of juvenile and adult koi, a strain of common carp. Journal of Aquatic Animal Health, 12: 44-57.

Noga, E.J. 1996. Fish Disease: Diagnosis and Treatment, Mosby-Yearbook, Inc., St. Louis, MO. Pp. 281, 294.

Office International des Epizooties. 2003. Diseases listed by the O.I.E. In: Aquatic Animal Health Code, Sixth Edition, OIE Aquatic Animal Health Standards Commission (Aquatic Animals Commission), Office International des Epizooties, Paris, France. http://www.oie.int/eng/normes/fcode/A_00005. htm

Ornamental Aquatic Trade Association (OATA). 2001. Koi Herpes Virus (KHV). OATA, Westbury, Wilts, UK. Pp. 4-33.

Perelberg, A., M. Smirnov, M. Hutoran, A. Diamant, Y. Bejerano, and M. Kotler. 2003. Epidemiological description of a new viral disease afflicting cultured Cyprinus carpio in Israel. The Israeli Journal of Aquaculture, 55(1): 5-12.

Ronen, A., A. Perelberg, J. Abramovitz, M Hutoran, S. Tinman, I. Bejerano, M. Steinitz, and M. Kotler. 2003. Efficient vaccine against the virus causing a lethal disease in cultured Cyprinus carpio. Vaccine 21(32): 4625-4743.

UF/IFAS Fact Sheet VM-142. 2002. Spring Viremia of Carp. University of Florida, Institute of Food and Agricultural Sciences.
Waltzek, T.B., Kelley, G.O., Yun, S.C., McDowell, T.S., Hedrick, R.P. 2004. Relationships of Koi Herpesvirus (KHV) to Herpes-like Viruses of Fish and Amphibians. In: Proceedings, 35th Annual Conference, International Association for Aquatic Animal Medicine, Galveston, TX, 35: 16-17.

\section{Further Reading}

Gray, W.L., L. Mullis, S.E. LaPatra, J.M. Groff, and A. Goodwin. 2002. Detection of koi herpesvirus DNA in tissues of infected fish. Journal of Fish Diseases 25: 171-178.

Fijan, N. 1999. Spring Viremia of Carp and Other Viral Diseases and Agents of Warm-water Fish. In Woo, P.T.K. and D.W. Bruno, eds., Fish Diseases and Disorders, Vol. 3: Viral, Bacterial, and Fungal Infections. CAB International Cambridge, UK. Pp. 177-244.

Wolf, K. 1988. Fish Viruses and Fish Viral Diseases. Cornell University Press, Ithaca, NY. Pp. 191-216, 253-263. 